\title{
SISTEM PENDUKUNG KEPUTUSAN SELEKSI SUPPLIER BAHAN BAKU DENGAN METODE SIMPLE ADDITIVE WEIGHTING (SAW)
}

\author{
Oke Hariansyah \\ Jurusan Teknik Informatika, Fakultas Teknik, Universitas Pamulang \\ Email: Dosen00840@unpam.ac.id
}

\begin{abstract}
Selection of suppliers for the company or the industry needs to be done to get the supplier truly able to meet the company's needs consistently. In this study, will be appointed a case of finding the best alternative based on the criteria that have been determined using the Fuzzy Multiple Attribute Decision Making (FMADM) Simple Additive Weighting method (SAW). This method was chosen because it is able to select the best alternative from a number of alternatives, in this case the alternative is intended to determine the best supplier based on specified criteria. Based on test results, the application of the system to be implemented to help the work of doing the selection of purchasing parts supplier, can speed up the process of selecting suppliers, and can facilitate the purchasing section chief part in determining the proper supplier selection, proper and appropriate

\begin{tabular}{l} 
Article History \\
\hline Received 2020-10-13 \\
Revised 2020-10-30 \\
Accepted 2020-11-02 \\
\hline Key words \\
\hline SPK \\
FMADM \\
SAW
\end{tabular}

ABSTRAK

Penyeleksian supplier bagi perusahaan atau dunia industri perlu dilakukan untuk mendapatkan supplier yang benar-benar mampu memenuhi kebutuhan perusahaan secara konsisten. Pada penelitian ini akan diangkat suatu kasus yaitu mencari alternative terbaik berdasarkan kriteria-kriteria yang telah ditentukan dengan menggunakan metode Fuzzy Multiple Attribute Decision Making (FMADM) dengan metode Simple Additive Weighting (SAW). Metode ini dipilih karena mampu menyeleksi alternative terbaik dari sejumlah alternative, dalam hal ini alternative yang dimaksudkan yaitu menentukan supplier terbaik berdasarkan kriteria-kriteria yang ditentukan. Berdasarkan hasil pengujian, alternatif (PCM) dengan bobot 0.9265 sehingga supplier ke 2 (PCM) layak atau dapat dijadikan alternative terbaik dalam pemilihan alternatif yang terpilih.
\end{abstract}

\section{PENDAHULUAN}

Fenomena yang terjadi pada perusahaan-perusahaan di Indonesia adalah memiliki lebih dari satu supplier bahan bakunya. Hal ini disebabkan pemenuhan aspek antisipasi pada kebutuhan bahan baku yang sering berubah dengan simpangan yang kurang menentu. Keadaan ini membawa perusahaan pada permasalahan pemilihan alternative supplier. Supplier yang dapat memberikan nilai efisiensi terbaik dengan kriteria yang diminta oleh perusahaan akan menjadi alternative terbaik (Jannah, 2011).

Kesalahan dalam pemilihan supplier bahan baku akan berdampak pada penurunan produktivitas perusahaan. Hal ini dikarenakan bahan baku merupakan salah satu faktor penting dalam kegiatan proses produksi karena berpengaruh secara langsung terhadap produk yang dihasilkan. Jika supplier kurang tanggap terhadap permintaan perusahaan maka akan berakibat terhentinya proses produksi karena lamanya waktu pengiriman (Jannah, 2011).

Pemilihan supplier perlu dilakukan untuk mendapatkan supplier yang benar-benar mampu memenuhi kebutuhan perusahaan secara konsisten. Proses pemilihan supplier dilakukan dengan cara melakukan evaluasi terhadap supplier dan membandingkannya dengan menggunakan ukuran dan kriteria yang sesuai (Setiawan, 2010).

Pada penelitian sebelumnya metode pengambilan keputusan telah banyak digunakan untuk berbagai penelitian. Rifyanu Fitra Budiman dalam Tugas Akhirnya yang berjudul "Pemilihan Supplier dengan Metode Topsis MCDM" melakukan perankingan dan menentukan supplier terbaik dengan obyek penelitian beberapa perusahaan penyedia jasa internet (ISP) (Wardhani, 2012).

Model yang akan digunakan kali ini dalam penerapan sistem pendukung keputusan untuk penyeleksian supplier ini akhirnya akan digunakan untuk mengetahui supplier terbaik adalah Fuzzy Multi Attribute Decision Making (FMADM). Secara umum, Fuzzy Multi Attribute Decision Making memiliki suatu tujuan tertentu (kriteria) dengan ciri-ciri terbaik dan mengklasifikasikan 
alternative berdasarkan peran tertentu (Simoes-Marques, 2000). Salah satu mekanisme untuk menyelesaikan masalah Fuzzy Multi Attribute Decision Making adalah dengan mengaplikasikan metode Multi Attribute Decision Making (MADM) klasik untuk melakukan perankingan setelah terlebih dahulu dilakukan konversi data fuzzy ke data crisp (Chen, 1992). Data yang bersifat fuzzy mengikuti suatu aturan sistem berbasis aturan fuzzy yang terdiri dari tiga komponen utama yaitu fuzzyfication, inference dan deffuzification agar dihasilkan nilai crisp. Simple Additive Weighting Method (SAW) salah satu metode Multi Attribute Decision Making klasik dipilih karena metode ini menentukan penjumlahan terbobot untuk setiap atribut. Dengan metode perankingan ini diharapkan penilaian akan lebih mudah dan tepat karena didasarkan pada nilai kriteria dan bobot yang sudah ditentukan sehingga akan mendapatkan hasil yang lebih akurat terhadap kinerja supplier (Harahaf, 2012).

Dari masalah diatas maka peneliti bermaksud untuk melakukan penerapan sistem pendukung keputusan dengan mengaplikasikan Microsoft Office Excel dengan judul "SISTEM PENDUKUNG KEPUTUSAN SELEKSI SUPPLIER BAHAN BAKU DENGAN METODE SIMPLE ADDITIVE WEIGHTING (SAW)".

\section{TINJAUAN PUSTAKA}

\section{Supplier Chain Management}

Supply Chain Management (SCM/Manajemen Rantai Pasok) merupakan sebuah pendekatan untuk diproduksi dan didistribusikan dalam jumlah yang tepat, lokasi yang tepat dan waktu yang tepat dalam rangka meminimalkan biaya dan meningkatkan kepuasan pelayanan (Mauidzoh dan Zuabidi, 2007) (Paramita, 2012).

Supplier merupakan salah satu bagian supply chain yang sangat penting dan berpengaruh terhadap kelangsungan hidup suatu perusahaan. Onut et al (2009) menjelaskan bahwa pemilihan supplier yang tidak tepat dapat mengganggu kegiatan operasional perusahaan, sedangkan pemilihan supplier yang tepat secara signifikan dapat mengurangi biaya pembelian, meningkatkan daya saing pasar dan meningkatkan kepuasan pengguna akhir produk (Paramita, 2012).

\section{Sistem Pendukung Keputusan (SPK)}

Ada berbagai macam pendapat tentang pengertian sistem pendukung keputusan. Sistem pendukung keputusan sebagai sebuah himpunan/kumpulan prosedur berbasis model untuk memproses data dan pertimbangan untuk membantu manajemen dalam pembuatan keputusannya (Little, 1970).

Sistem pendukung keputusan adalah sistem berbasis komputer yang dibangun lewat sebuah proses adaptif dari pembelajaran, pola-pola penggunan dan evolusi system (Keen,1980).

Sistem pendukung keputusan sebagai sebuah sistem berbasis komputer yang terdiri atas komponen-komponen antara lain komponen sistem bahasa (language), komponen sistem pengetahuan (knowledge) dan komponen sistem pemrosesan masalah (problem processing) yang saling berinteraksi satu dengan yang lainnya (Bonczek 1980).

Pada dasarnya pengambilan keputusan adalah suatu pendekatan sistematis pada hakekat suatu masalah, pengumpulan fakta-fakta, penentuan yang matang dari alternatif yang dihadapi, dan pengambilan tindakan yang menurut perhitungan merupakan tindakan yang paling tepat.

\section{Himpunan Klasik (Crips)}

Pada dasarnya, teori himpunan fuzzy merupakan perluasan dari teori himpunan klasik. Pada teori himpunan klasik (crips), keberadaan suatu elemen pada suatu himpunan, A, hanya akan memiliki 2 kemungkinan keanggotaan, yaitu menjadi anggota $\mathrm{A}$ atau tidak menjadi anggota $\mathrm{A}$ (Chak, 1998). Suatu nilai yang menunjukan seberapa besar tingkat keanggotaan suatu elemen (x) dalam suatu himpunan (A), sering dikenal dengan nama nilai keanggotaan atau derajat keanggotaan, dinotasikan dengan $\mu \mathrm{A}(\mathrm{x})$. pada himpunan klasik, hanya ada 2 nilai keanggotaan, yaitu $\mu \mathrm{A}(\mathrm{x})=1$ untuk $\mathrm{x}$ menjadi anggota $\mathrm{A}$; dan $\mu \mathrm{A}(\mathrm{x})=0$ untuk $\mathrm{x}$ bukan anggota dari $\mathrm{A}$ (Setiawan, 2010). 


\section{FMADM (Fuzzy Multiple Attribute Decission Making)}

Pada dasarnya, proses MADM dilakukan melalui 3 tahap, yaitu penyusunan komponenkomponen situasi, analisis, dan sintesis informasi (Rudolphi, 2000). Pada setiap penyusunan komponen, komponen situasi, akan dibentuk table taksiran yang berisi identifikasi alternatif dan spesifikasi tujuan, kriteria dan atribut. Salah satu cara untuk menspesifikasikan tujuan situasi | Oi' $\mathrm{i}=1, \ldots, \mathrm{t} \mid$ adalah dengan cara mendaftar konsekuensi-konsekuensi yang mungkin dari alternatif yang telah teridentifikasi $\mid$ Ai' $\mathrm{i}=1, \ldots, \mathrm{n} \mid$. Selain itu juga disusun atribut-atribut yang akan digunakan $\mid \mathrm{ak}$ ' $\mathrm{k}=1, \ldots \mathrm{m} \mid$ (Yeh, 2002). lain:

Ada beberapa metode yang dapat digunakan untuk mnyelesaikan masalah FMADM. antara

a) Simple Additive Weighting Method (SAW)

b) Weighted Product (WP)

c) ELECTRE

d) Technique for Order Preference by Similarity to Ideal Solution (TOPSIS)

e) Analytic Hierarchy Process (AHP)

\section{(SAW) Simple Additive Weighting}

Metode SAW sering juga dikenal istilah metode penjumlahan terbobot. Konsep dasar metode SAW adalah mencari penjumlahan terbobot dari rating kinerja pada setiap alternatif pada semua atribut. Metode SAW membutuhkan proses normalisasi matriks keputusan (X) ke suatu skala yang dapat diperbandingkan dengan semua rating alternative yang ada (Setiawan, 2010).

Keterangan :

$$
r_{i j}= \begin{cases}\frac{x_{i j}}{\operatorname{Max}_{i}} & \text { jika jadalah atribut keuntungan (benefit) } \\ \frac{\operatorname{Min}_{i} x_{i j}}{x_{i j}} & \text { jika jadalah atribut biaya (cost) }\end{cases}
$$

$r_{i j}=$ nilai rating kinerja ternormalisasi

$x_{i j}=$ nilai atribut yang dimiliki dari setiap kriteria

$\operatorname{Max}_{i} x_{i j}=$ nilai terbesar dari setiap kriteria

$\operatorname{Min}_{i} x_{i j}=$ nilai terkecil dari setiap kriteria

benefit $=$ jika nilai terbesar adalah terbaik

cost $\quad=$ jika nilai terkecil adalah terbaik

dimana rij adalah rating kinerja ternormalisasi dari alternatif $\mathrm{Ai}$ pada atribut $\mathrm{Cj}$; $\mathrm{i}=1,2, \ldots, \mathrm{m}$ dan $\mathrm{j}=1,2, \ldots, \mathrm{n}$. Nilai preferensi untuk setiap alternative $(\mathrm{Vi})$ diberikan sebagai:

$$
V_{i}=\sum_{j=1}^{n} w_{j} r_{i j}
$$

Keterangan :

$V_{i}=$ rangking untuk setiap alternatif

$w_{j}=$ nilai bobot dari setiap kriteria

$r_{i j}=$ nilai rating kinerja ternormalisasi

Nilai Vi yang lebih besar mengindikasikan bahwa alternatif Ai lebih terpilih. 


\section{METODE}

Jenis Penelitian yang digunakan dalam penelitian ini adalah model eksperimen. Penelitian ini menggunakan Simple Additive Weighting $(S A W)$ untuk memudahkan bagian Departemen Purchasing dalam melakukan penyelekian supplier dalam penentuan pembagian order pada supplier. Jenis data yang digunakan dalam penelitian ini adalah data primer yang diperoleh penulis secara langsung dari sumber dengan melakukan pengambilan data supplier melalui karyawan yang berwenang.

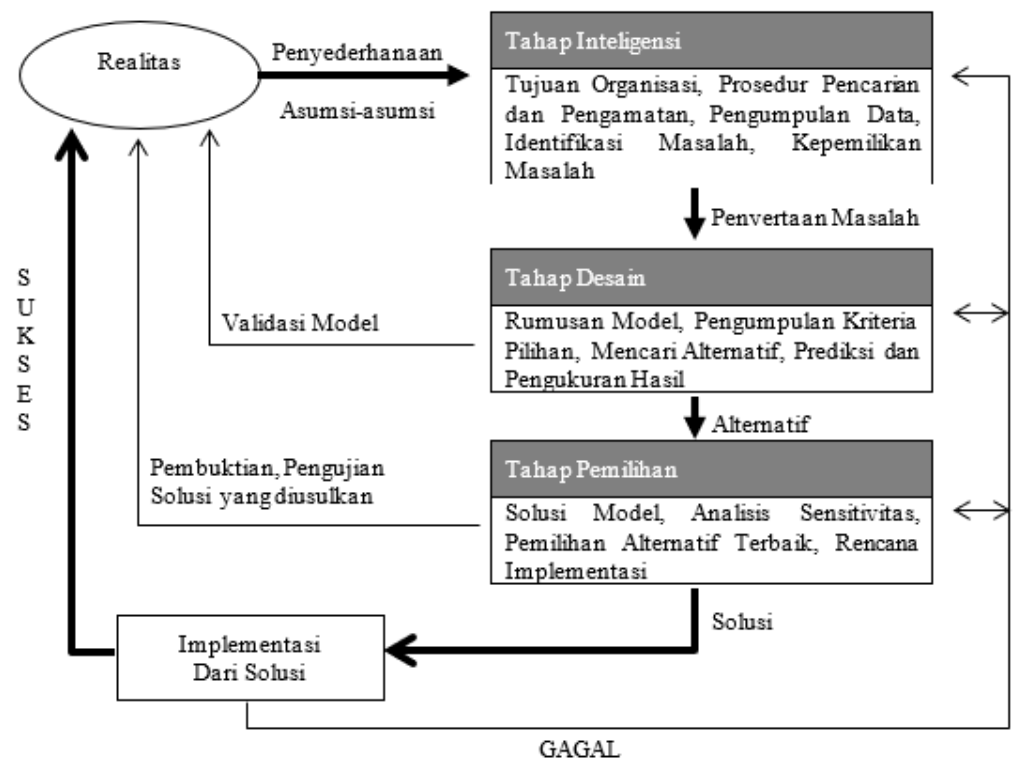

Gambar 1 Tahap pengambilan keputusan

Dari gambar diatas dapat dilihat tahapan untuk pengambilan keputusan untuk penelitian ini. Pertama adalah tahapan intelegensi, yang disertai permasalahan. Kedua tahap desain yaitu perumusan model dan pengumpulan kriteria. Ketiga tahap pemilihan, yang semaunya masuk kedalam implementasi untuk mendapatkan sebuah solusi.

Dari data supplier yang di dapat, diambil 3 (tiga) supplier sebagai contoh untuk penerapan metode Fuzzy Multiple Attribute Decision Making (FMADM) dengan metode Simple Additive Weighting $(S A W)$ untuk menilai supplier dalam penyeleksian supplier terbaik yang bertujuan akhir untuk penentuan pembagian jumlah order dari tiap-tiap supplier. Data-data dari tiap supplier tersebut di masukan ke dalam Tabel 1 di bawah ini.

Tabel 1 Data List Supplier

\begin{tabular}{|c|c|c|c|c|c|c|c|}
\hline No & $\begin{array}{c}\text { Kode } \\
\text { Supplier }\end{array}$ & $\begin{array}{c}\text { Kode } \\
\text { Barang }\end{array}$ & Harga & Qty Order & $\begin{array}{c}\text { Qty } \\
\text { Terima }\end{array}$ & $\begin{array}{l}\text { Tgl } \\
\text { Oder }\end{array}$ & $\begin{array}{c}\text { Tgl } \\
\text { Terima }\end{array}$ \\
\hline 1 & TIM & 3051001002 & 75 & 984.000 & 984.000 & $21 / 3 / 13$ & $30 / 4 / 13$ \\
\hline 2 & PCM & 3051001002 & 94 & 864.000 & 864.000 & $21 / 3 / 13$ & $29 / 4 / 13$ \\
\hline 3 & TSSI & 3051001002 & 75 & 864.000 & 864.000 & $21 / 3 / 13$ & $29 / 4 / 13$ \\
\hline \multicolumn{4}{|c|}{ Total } & 2.712 .000 & 2.712 .000 & & \\
\hline
\end{tabular}

\section{HASIL DAN PEMBAHASAN}

Penyeleksian untuk menentukan supplier dengan menggunakan metode Fuzzy Multiple Attribute Decision Making (FMADM) dengan metode Simple Additive Weighting (SAW), maka yang harus dilakukan yaitu:

Memberikan nilai setiap alternatif pada setiap kriteria yang sudah ditentukan. Kualitas "Q" (Quality) Pada variabel mutu produk terdiri dari empat bilangan fuzzy, 
yaitu Tidak Bagus (TB), Sedang (S), Bagus (B), dan Sangat Bagus (SB) seperti terlihat pada Gambar 3-2.

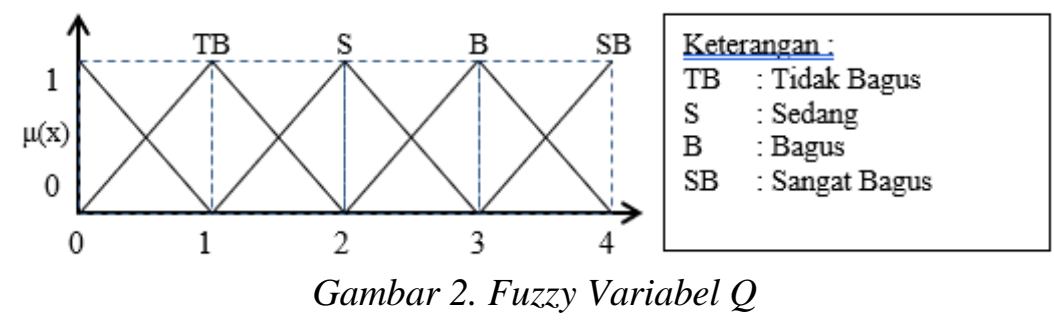

Dari gambar diatas, bilangan-bilangan fuzzy dapat dikonversikan ke bilangan crisp. Untuk memberikan nilai keanggotaan pada setiap bilangan fuzzy. Untuk lebih jelas data kualitas dibentuk dalam tabel di bawah ini.

Tabel 2 Kualitas

\begin{tabular}{|c|c|c|}
\hline Berdasarkan Kualitas $\left(\mathrm{C}_{1}\right)$ & Bilangan fuzzy & Nilai \\
\hline 0,00 & Sangat Bagus & 4 \\
\hline $0,01 \mathrm{~s} / \mathrm{d} 0,50$ & Bagus & 3 \\
\hline $0,51 \mathrm{~s} / \mathrm{d} 1,00$ & Sedang & 2 \\
\hline Diatas 1,00 & Tidak Bagus & 1 \\
\hline
\end{tabular}

Harga "C" (Cost)

Pada variabel Harga nilai keanggotaan yang diberikan adalah nilai dari harga sebenarnya yang sudah disepakati bersama, biasanya perubahan harga akan ditentukan dalam kurun waktu tertentu, bisa satu tahun 1 kali atau 1 tahun 2 kali, dan penentuan tersebut biasa diajukan oleh pihak supplier disaat memang biaya produksi mereka sudah harus naik.

Pengiriman "D” (Delivery)

Pada variabel pengiriman terdiri dari empat bilangan fuzzy, yaitu Tidak Bagus (TB), Sedang (S), Bagus (B), dan Sangat Bagus (SB) seperti terlihat pada Gambar berikut:

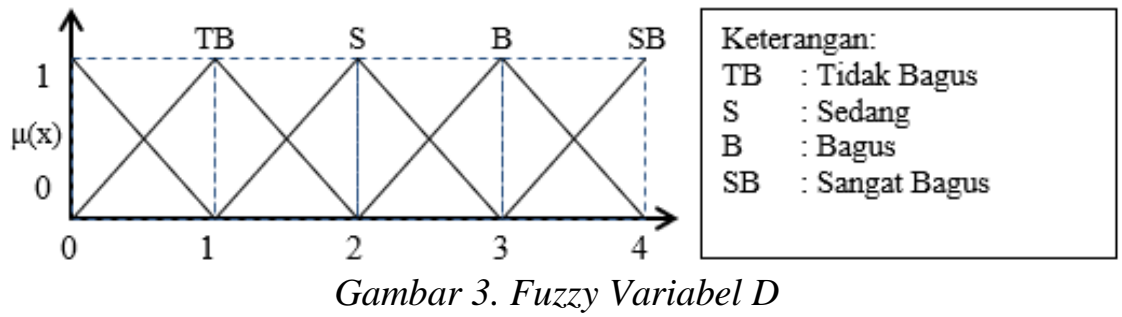

Dari gambar diatas, bilangan-bilangan fuzzy dapat dikonversikan ke bilangan crisp. Untuk memberikan nilai keanggotaan pada setiap bilangan fuzzy. Untuk lebih jelas data pengiriman dibentuk dalam tabel di bawah ini.

Tabel 3 Pengiriman

\begin{tabular}{|l|c|c|}
\hline \multicolumn{1}{|c|}{ Berdasarkan pengiriman (C3) } & Bilangan fuzzy & Nilai \\
\hline $\begin{array}{l}\text { Pengiriman tepat waktu (tidak terlambat) dan dapat memenuhi } \\
\text { kuantitas yang di pesan. }\end{array}$ & Sangat Bagus & 4 \\
\hline Terlambat 1 hari & Bagus & 3 \\
\hline Terlambat $1-3$ hari & Sedang & 2 \\
\hline Terlambat lebih dari 3 hari & Tidak Bagus & 1 \\
\hline
\end{tabular}


Setelah semua pengkonversian dan memberikan nilai keanggotaan pada setiap bilangan fuzzy selesai. Maka selanjutnya harus menunjukan rating kecocokan dari setiap alternative yang sudah ditentukan pada tabel 3-3 ke setiap kriteri-kriteria diatas yaitu Kualitas, Harga dan Pengiriman.

Tabel di bawah ini menunjukan rating kecocokan dari setiap alternative pada setiap kriteria diatas.

Tabel 4 Rating kecocokan dari setiap alternatif pada setiap kriteria

\begin{tabular}{|c|c|c|c|}
\hline \multirow{2}{*}{ Alternatif } & \multicolumn{3}{|c|}{ Kriteria } \\
\cline { 2 - 4 } & $\mathrm{C}_{1}(\mathrm{Q})$ & $\mathrm{C}_{2}(\mathrm{C})$ & $\mathrm{C}_{3}(\mathrm{D})$ \\
\hline TIM & 2 & 75 & 3 \\
\hline PCM & 3 & 94 & 4 \\
\hline TSSI & 2 & 75 & 4 \\
\hline
\end{tabular}

Dari tabel diatas rating kecocokan untuk kriteria C1 (Kualitas) nilai keanggotaan didapat dari data quality control yang ditetapkan oleh Depatemen Quality Assuance dimana mereka memberikan hasil penilaian quality setiap bulannya kepada Departemen Purchasing dari total claim bahan baku.

Rating kecocokan untuk kriteria C2 (Harga) nilai keanggotaan didapat dari hasil kesepakatan kedua belah pihak melalui penawaran harga.

Rating kecocokan untuk kriteria C3 (Pengiriman) nilai keanggotaan didapat dari data pengiriman barang yang dilaporkan oleh Departemen Product Planning tepatya seksi Warehouse Material.

Langkah selanjutnya adalah merubah nilai keanggotaan pada rating kecocokan kedalam matriks keputusan X seperti dibawah ini:

$$
X=\left(\begin{array}{lll}
2 & 75 & 3 \\
3 & 94 & 4 \\
2 & 75 & 4
\end{array}\right)
$$

Memberikan nilai bobot $(\mathrm{W})$.

Untuk menentukan nilai pada setiap ktiteria-kriteria yang sudah ditentukan maka penentuan pembobotan dibagi menjadi $45 \%$ untuk C1 (Kualitas), 35\% untuk C2 (Harga) dan $20 \%$ untuk C3 (Pengiriman) dan dibentuk dalam tabel seperti di bawah ini:

Tabel 5 Bobot untuk kriteria

\begin{tabular}{|c|c|c|}
\hline Kriteria & Bobot & Nilai \\
\hline C1 & Sangat Bagus (SB) & $45 \%$ \\
\hline C2 & Bagus (B) & $35 \%$ \\
\hline C3 & Sedang (S) & $20 \%$ \\
\hline
\end{tabular}

Dari Tabel 5 diatas maka pengambil keputusan memberikan bobot $(\mathrm{W})$ preferensi sebagai berikut:

$$
\mathrm{W}=\left[\begin{array}{lll}
0.45, & 0.35,0.2
\end{array}\right]
$$

Nilai W diatas adalah konversi presentase pada tabel 3-7 ke kedalam bilang dibawah 1 (satu) atau nilai asli dari presentase tersebut. Dan menghasilkan nilai 0,45 untuk C1 (Kualitas), 0,35 untuk C2 (Harga) dan 0.2 untuk C3 (Pengiriman). 
Menormalisasi matriks X menjadi matriks R berdasarkan persamaan 1.

$$
r_{i j}= \begin{cases}\frac{x_{i j}}{\operatorname{Max}_{i}} & \text { jika jadalah atribut keuntungan (benefit) } \\ \frac{\operatorname{Min}_{i} x_{i j}}{x_{i j}} & \text { jika jadalah atribut biaya (cost) }\end{cases}
$$

Keterangan :

$\begin{array}{lll}r_{i j} & = & \text { nilai rating kinerja ternormalisasi } \\ x_{i j} & = & \text { nilai atribut yang dimiliki dari setiap kriteria } \\ \underset{i}{\operatorname{Max}_{i j}}= & \text { nilai terbesar dari setiap kriteria } \\ \operatorname{Min}_{i} x_{i j} & & \text { nilai terkecil dari setiap kriteria } \\ \text { benefit } & = & \text { jika nilai terbesar adalah terbaik } \\ \text { cost } & = & \text { jika nilai terkecil adalah terbaik }\end{array}$

Dari kegita kriteria yang sudah ditentukan diatas maka ditetapkan kriteria pertama dan kriteria ketiga adalah kriteria keuntungan. Sedangkan kriteria kedua dianggap sebagai kriteria biaya. Dikarenakan kriteria kedua adalah nilai terkecil adalah nilai teraik, seperti dijelaskan pada keterangan diatas.

Dari penetapan kriteria diatas maka langkah yang harus dilakukan berikutnya adalah menormalisasi matriks $\mathrm{X}$ berdasarkan persamaan (1). langkah-langkahnya sebagai berikut:

Untuk Kualitas "Q"

Diabawah ini adalah proses perhitungan persamaan 1 untuk kriteria pertama $(\mathrm{C} 1)$

$$
\begin{aligned}
& r_{11}=\frac{2}{\max \{2 ; 3 ; 2\}}=\frac{2}{3}=0,67 \\
& r_{21}=\frac{3}{\max \{2 ; 3 ; 2\}}=\frac{3}{3}=1 \\
& r_{31}=\frac{2}{\max \{2 ; 3 ; 2\}}=\frac{2}{3}=0,67
\end{aligned}
$$

Dari perhitungan diatas untuk perhitungan kriteria keuntungan maka bisa kita lihat bahwa nilai rating kinerja ternormaliasasi (rij) adalah nilai atribut yang dimiliki dari setiap kriteria dibagi nilai terbesar dari setiap kriteria dan akan menghasilkan nilai rating kinerja ternormalisasi atau rij.

Untuk Harga "C"

Dibawah ini adalah proses perhitungan persamaan 1 untuk kriteria kedua (C2) .

$$
\begin{aligned}
& r_{11}=\frac{\min \{75 ; 94 ; 75\}}{75}=\frac{75}{75}=1 \\
& r_{11}=\frac{\min \{75 ; 94 ; 75\}}{94}=\frac{75}{94}=0.79 \\
& r_{11}=\frac{\min \{75 ; 94 ; 75\}}{75}=\frac{75}{75}=1
\end{aligned}
$$


Dari perhitungan diatas untuk perhitungan kriteria baiaya maka bisa kita lihat bahwa nilai rating kinerja ternormaliasasi (rij) adalah nilai terkecil dari setiap kriteria dibagi nilai atribut yang dimiliki dari setiap kriteria dan akan menghasilkan nilai rating kinerja ternormalisasi atau rij.

Untuk pengiriman " $\mathrm{D}$ "

Dibawah ini adalah proses perhitungan persamaan 1 untuk kriteria pertama (C3)

$$
\begin{aligned}
& r_{13}=\frac{3}{\max \{3 ; 4 ; 4\}}=\frac{3}{4}=0.75 \\
& r_{13}=\frac{4}{\max \{3 ; 4 ; 4\}}=\frac{4}{4}=1 \\
& r_{13}=\frac{4}{\max \{3 ; 4 ; 4\}}=\frac{4}{4}=1
\end{aligned}
$$

Dari perhitungan diatas untuk perhitungan kriteria keuntungan maka bisa kita lihat bahwa nilai rating kinerja ternormaliasasi (rij) adalah nilai atribut yang dimiliki dari setiap kriteria dibagi nilai terbesar dari setiap kriteria dan akan menghasilkan nilai rating kinerja ternormalisasi atau rij.

Dari hasil perhitungan normalisasi matriks X berdasarkan persamaan (1). Maka langkah berikutnya yang harus dilakukan adalah merubah haril dari perhitungan persamaan 1 kedalam matrik R.

Dibawah ini adalah Matriks R dari persamaan (1) :

$$
X=\left(\begin{array}{lll}
0.67 & 1 & 0.75 \\
1 & 0.79 & 1 \\
0.67 & 1 & 1
\end{array}\right)
$$

Melakukan proses perankingan dengan menggunakan persamaan (2):

Keterangan :

$$
V_{i}=\sum_{j=1}^{n} w_{j} r_{i j}
$$

$V_{i}=$ rangking untuk setiap alternatif

$w_{j}=$ nilai bobot dari setiap kriteria

$r_{i j}=$ nilai rating kinerja ternormalisasi dibawah ini.

Proses perankingan dengan menggunakan bobot yang telah diberikan pada tabel 3-8 seperti

$$
\mathrm{W}=\left[\begin{array}{lll}
0,45 & 0,35 \quad 0,2
\end{array}\right]
$$

Dari bobot diatas maka nilai bobot dari setiap kriteria akan dikalikan dengan nilai-nilai Matriks R dari persamaan (1). Langkah-langkahnya sebagai berikut:

$$
\begin{array}{ll}
\text { V1 } & =(0.45)(0.67)+(0.35)(1)+(0.2)(0.75) \\
& =0,3015+0.35+0,15 \\
& =0.815 \\
& =(0.45)(1)+(0.35)(0.79)+(0.2)(1) \\
& =0.45+0.2765+0.2 \\
& =0.9265 \\
\text { V3 } \quad & =(0.45)(0.67)+(0.35)(1)+(0.2)(1) \\
& =0.3015+0.35+0.2 \\
& =0.8515
\end{array}
$$


Dari perhitungan diatas bisa dijabarkan bahwa rangking untuk setiap alternative adalah nilai bobot dikalikan dengan nilai matriks $\mathrm{R}$ dari persamaan (1) dan ditambah dari hasil perkalianperkalian bobot dengan nilai matriks $\mathrm{R}$ dari persamaan (1) dan menghasilkan nilai perangkingan persamaan (2).

Dari perhitungan diatas didapat hasil penilaian terbesar ada pada V2 yaitu Supplier ke 2 (PCM) dengan bobot 0.9265 sehingga supplier ke 2 (PCM) layak atau dapat dijadikan alternative terbaik dalam pemilihan alternatif yang terpilih. Untuk lebih jelas lihat pada tabel 3-8:

\section{Tabel 6 Ranking}

\begin{tabular}{|c|c|c|c|c|c|}
\hline No & Nama Supplier & $\begin{array}{c}\text { Qualitas } \\
(\mathrm{C} 1 / \mathrm{Q})\end{array}$ & $\begin{array}{c}\text { Harga } \\
(\mathrm{C} 2 / \mathrm{C})\end{array}$ & $\begin{array}{c}\text { Pengiriman } \\
(\mathrm{C} 3 / \mathrm{D})\end{array}$ & Hasil Akhir \\
\hline 1 & TIM & 0.3015 & 0.35 & 0.15 & 0.815 \\
\hline 2 & PCM & 0.45 & 0.2765 & 0.2 & 0.9265 \\
\hline 3 & TSSI & 0.3015 & 0.35 & 0.2 & 0.8515 \\
\hline
\end{tabular}

Nilai-nilai dari tabel diatas adalah nilai yang diambil dari hasil perkalian antara nilai bobot dengan nilai matriks $\mathrm{R}$ dari persamaan (1) dan hasil dari perkalian dimasukan ke tabel berdasarkan kriteriakriteria diatas yaitu $(\mathrm{C} 1 / \mathrm{Q})$, (C2/C) dan $(\mathrm{C} 3 / \mathrm{D})$. dan pada kolom hasil akhir adalah nilai dari penjumlahan antara $\mathrm{C} 1$ sampai dengan $\mathrm{C} 3$.

\section{KESIMPULAN}

Setelah penulis melakukan pengamatan pada masalah yang ada, penulis melakukan penerapan perhitungan dengan menggunakan Metode Simple Additive Weigting (SAW). Maka didapat hasil penilaian terbesar ada pada V2 yaitu Supplier ke 2 (PCM) dengan bobot 0.9265 sehingga supplier ke 2 (PCM) layak atau dapat dijadikan alternative terbaik dalam pemilihan alternatif yang terpilih.

\section{DAFTAR PUSTAKA}

[1] Harahap, Mara Halim (2012). Sistem Pendukung Pengambilan Keputusan Penilaian Kinerja Karyawan Dengan Metode Simple Additive Weighting (SAW) Studi Kasus PT. BANK TABUNGAN NEGARA (Persero).Tbk.

[2] Jannah, Miftakhul. Fakhry, Muhammad \& Rakhmawati (2011). Pengambilan Keputusan Untuk Untuk Pemilihan Supplier Bahan Baku Dengan Pendekatan Analytic Hierarchy Process Di PR Pahala Sidoarjo

[3] Komarudin, G. A. (2012). Sistem Pendukung Keputusan Pemilihan balai Pengobatan Menggunakan Fuzzy Multiple Attribute Decission Making (FMADM) (studi Kasus : Kota Cimahi). Seminar Nasional Ilmu Komputer Universitas Diponegoro (p. 54). Yogyakarta: Graha Ilmu.

[4] Para madina, Luky (2009). Sistem Pendukung Keputusan

[5] Setiawan, Guruh (2010). Sistem Pendukung Keputusan Seleksi Supplier Dalam Pemilihan Supplier Sparepart Terbaik PT. Federal Nittan Industries

[6] Subakti, Irfan (2002). Sistem Pendukung Keputusan (Decision Support System). 